\title{
The Effects of Government Policy on Craftsmen Welfare in Badung Regency of Bali Province; Mediating by Social Infrastrcture, Entrepreneurship, and Competitive Resources
}

\author{
I Gede Wijaya ${ }^{1}$, I Made Suyana Utama ${ }^{2}$, \\ Made Kembar Sri Budhi ${ }^{3}$, I Gede Sudjana Budhiasa ${ }^{4}$ \\ ${ }^{I}$ Doctorate Candidate from Faculty of Economic and Business of Udayana Univeristy, Indonesia \\ ${ }^{2,3,4}$ Lecture from Faculty of Economic and Business of Udayana University, Indonesia
}

\begin{abstract}
Export craft of Badung regency, Bali Province, during the five years has decreased. Therefore, it becomes extremely relevant to collate and analyze the theoretical model in order to drive performance improvement and expansion of the international market segments on the craft, so as to achieve the export performance craft such as the period before five years ago. This study aims to determine the role of social infrastructure, entrepreneurship, and the competitive resources in mediating the effects of government policies on the craftsmen welfare in Badung. Data analysis was performed using SEM-PLS. The results showed that direct, government policy not significant effect on the welfare of craftsman. Therefore, public policy should be realized through various programs and activities to support the craft business conditions so as to realize the craftsman welfare. Furthermore, that the role of social infrastructure, entrepreneurship, and competitive resources proven to mediate significantly the influence of government policies on the craftsmen welfare. Some examples of government programs recommended to improve the craftsman welfare is to facilitate the sale of products through exhibitions, conducting management training and technology, as well as the expansion of craft products.
\end{abstract}

Keywords: Craftsmen Welfare, Government Policy, Social Infrastructure, Entrepreneurship, Competitive Resources

\section{Introduction}

Bali is a popular tourist destination in the world. Badung Regency is one of the areas in the province of Bali is a favorite of tourists to settle in Bali, as evidenced by the highest hotel occupancy rate is in Badung. One of the sectors that support tourism activities is the craft industry. Badung regency also has potential in the field of handicrafts, has even penetrated the international market. However, in recent years, the value of non-oil exports (including crafts) in Badung experiencing a downward trend as shown in Figure 1.

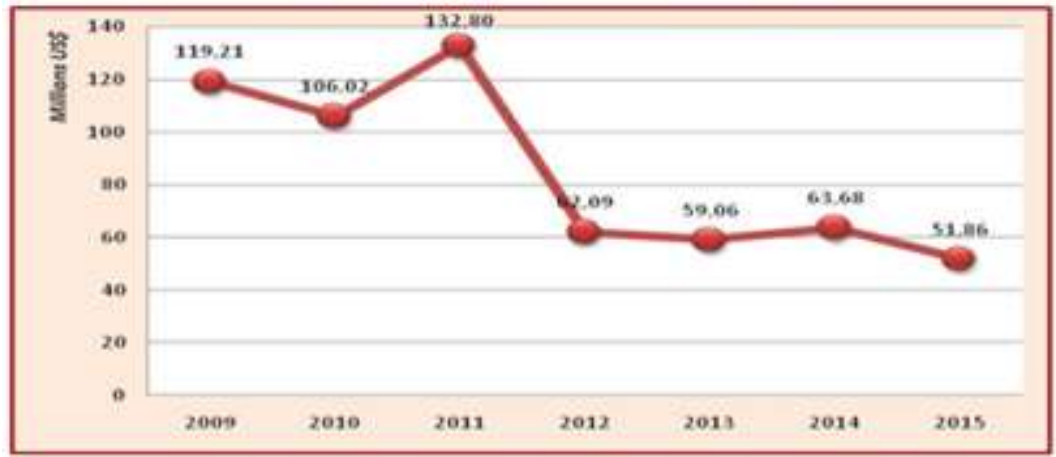

Figure 1: Trend Nilai Ekspor Non Migas di Kabupaten Badung, Tahun 2009 - 2015 Source: Central Bureau of Statistic at Badung Regency

Most of the non-oil export commodities Badung derived from the craft, as the chart in Figure 2. The total value of non-oil exports in the Badung regency of 2014 amounted to US $\$ 63,675,447.62$. The largest contribution given by the craft commodity is US $\$ 32,409,884.02$ (50.90\%) followed by commodities industry at US \$27,177,767.97 (42.68\%), while agricultural commodities contribute US \$ 3,564 .365,9 (5.6\%), commodities estate products amounted to US \$ 440,092.78 (0.69\%) and other commodities amounted to US \$ $83,336.95(0.13 \%)$. Therefore, the craft sector in the Badung regency should receive full support from the government. 


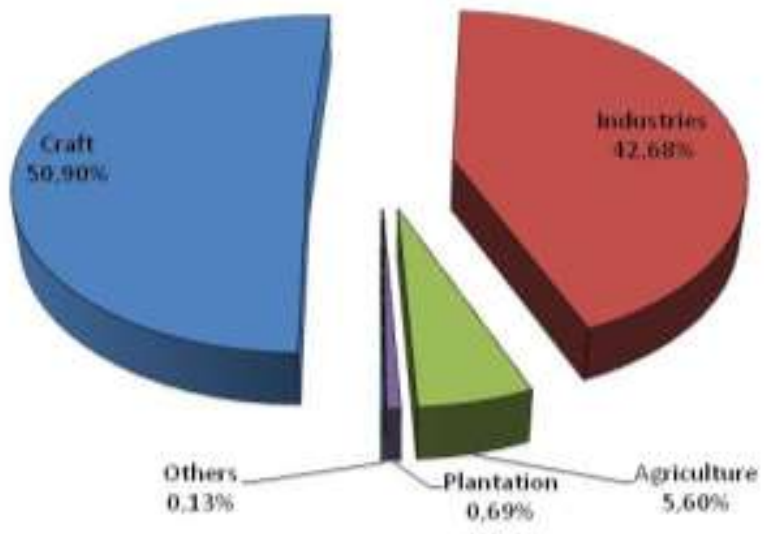

Figure 2: Percentage of Commodity Which Have Contributed to Export of Badung Regency, Year 2009 - 2015 Source: Central Bureau of Statistic at Badung Regency

Research problems are formulated is that the performance of craft businesses is not optimal that lead has been a decline in the export trade of handicraft products in the last four years. The performance is not optimal due to the absence of effort sufficient of craftsmen when the pressure of the global market occur, as referred from Leibenstein and Maital (1992). The performance is not optimal described by the condition of not achieving optimal efficiency of resource businesses to response the dynamics market pressure, referring to the x-Efficiency theory of Leibenstein and Maital (1992), so that the business can not achieve the competitiveness required, and also in turn unformed welfare to encourage the strengthening of innovation and creativity of production.

The purpose of this study is to analyze the direct influence of the various factors that affect the welfare of craftsman, namely: government policy, social infrastructure, entrepreneurship, and competitive resources. Further analysis also indirectly influence government policies on the craftsman welfare with the mediation of social infrastructure, entrepreneurship, and competitive resources.

\section{Theory of Welfare}

\section{Literature Review}

Theorywelfare in general can be classified into three kinds, namely classical utilitarian, neoclassical welfare theory and new contractarian approach (Albert and Hahnel, 1990). Classical utilitarian approach emphasizes that the pleasure or satisfaction a person can be measured and grow. Principles for individuals is increasing the level of welfare as much as possible, while improving the welfare for the people of the group is the principle held in his life. Neoclassical welfare theory approach explains that the welfare function is a function of all the individual satisfaction. Other developments in the theory of social welfare is the emergence of new contractarian approach that raised the maximum freedom in lives of individual or someone. It is most emphasized in the new contractarian approach is the individuals will maximize their freedom to pursue their concept of goods and services without any interference.

Theory of economics welfare studying various conditions under which the solution of equilibrium models generally can be said to be optimal. This requires, among others, the optimal allocation of factors of production among consumers (Salvatore, 1997). There are various levels of development of the measurement of the physical well-being, such as the Human Development Index, Physical Quality LifeIndex, Basic Needs, and GNP. The size of the economic welfare of the program can be seen from two sides, namely consumption and production (scale enterprises). In terms of consumption, welfare can be measured by calculating how much expenditures to a person or a family for clothing, food, shelter, and other necessities in time or a certain period.

Over the last 20 years, studies on the welfare of the community has grown, not only limited to the nominal size, but expanded to the field of non-economic study, so the concept has been modeled as a welfare measure the quality of life (wesgate, 1996; Kamya, 2000). The quality of life is stated to have dimensions of religious well-being (Tsung, 2002). Spiritual well-being is stated to have a component related to the dimensions of public health, physical and social conditions, as well as the intellect factor (Ellison and Smith, 1991; Chandler etal.,1992; Kamya, 2000).

The definition of spiritual well-being is also described as a behavior which is too religious, a good understanding of the purpose and nature of life, aligning themselves to achieve happiness and the view that life is the complexity of many destinations (Adams etal.,2000). Tsung et al.(2002), states that the dimensions of existential well-being is related to life satisfaction and mental health and psychological level. Thus, in contrast to the concept of welfare nominal measurements, then the welfare approach as developed by a number of researchers Ellison and Smith (1991), Chandler et al.(1992), Wesgate (1996), Kamya (2000), Tsung et al. 
(2002), the outline provides guidance on the measurement of the welfare level in a more holistic by inserting non-economic as a pattern of measuring well-being, because human beings are creatures of dynamic and complex (Adams et al, 2000; Tsung et al, 2002).

\section{Government Policy}

Birth of government in the beginning is to maintain a system of order in masyasrakat, so that the people can live a life as normal. Along with the development of modern society characterized by increasing needs, the role of government then changed to serve the community. Modern government, in other words, is essentially a service to the community. Governments were held not to serve theirselves, but to serve the community, create conditions that allow each member to develop the ability and creativity in order to achieve progress together (Al Rashid, 2000).

Osborne and Gaebler (Al Rashid, 2000), even stated that a democratic government is born to serve its citizens and therefore the task of the government is looking for ways to delight its citizens. Thus the birth of the government to provide an understanding that the presence of a government is a manifestation of the will of the public to do good for the benefit of society, even Van Poelje (in Hamdi, 1999) asserted that, government can be viewed as a science that teaches how best to direct and led public services. Ndraha (2000), said that the government holds the responsibility for the people's interests. Further Ndraha also said that the government is all loads that produce, distribute, or sell the appliance meet community needs in the form of public services and the civil service.

No country in the world that does not to involve the government role in the economic system. Not even in countries that follow the capitalist system that requires more dominant role of private sector in managing the economy. Since none of the capitalist countries in the world that embraces the pure capitalist system. According to Adam Smith, capitalist economists, put forward his theory that everything in the economy will operate independently adjust towards equilibrium according to the market mechanism. Attraction force in the economic system as controlled by"the invisible hand", and thus does not require so much government interference. And then by Adam Smith the role of government includes only three functions, namely to keep the security and defense of the country, organizing the judiciary, providing goods that can not be provided by the private sector. In the present time, numerous developments and advances due to the rapid advancement of technology and the many new inventions and increasingly the open economy between countries, causing so much interest that relate and collide. This led the government's role is increasingly needed in regulating the running of the economy, because it is not fully all areas of the economy that can be handled by the private sector. Thus in the modern economic system, the government's role can be divided into three parts, namely the role allocation, role distribution, and stabilization role.

Within the framework of the perspective competitiveness developments of enterprises, the government policy plays a decisive facilitator in founding formal and non-formal institution (North, 1990). The recent government policy can also be enabled through the cooperation of government, business and society. The integration of the three known within the framework of Corporate Social Responsibility policy, which invites governments and the business world to build a welfare of society.

\section{Social Infrastructure and Entrepreneurship}

The concept of the theory that developed by Flora and Flora (1993), about enterpreneural social infrastructure is the theoretical framework that was built in order to facilitate institutions to strengthen the presence of entrepreneurs into growing. Therefore, it can be stated that the social entrepreneurs infrastructure network is strengthening the network communities in order to strengthen creativity and innovation, especially in rural communities in the United States as research areas of Flora and Flora (1993).

Institutional strengthening in order to develop creativity and innovation climate that has been formed in rural communities, should be guided by establishing a framework of a system that allows the maintenance of the creativity of entrepreneurs in a sustainable manner. Flora and Flora (1993), outlines three (3) components, namely symbolic diversity, mobilization ofresources, and network quality. Symbolic diversity is a process of collective action on the rural communities activity that tend to have proximity to one another with a private interpersonal one another informally. The second dimension of entrepreneurs social infrastructure is the mobilization of resources as a local resource resilience in facing the challenges of business and market competition. The third dimension of the entrepreneurs social infrastructure is network quality, which resulted in the foundation reinforcement pace of innovation and creativity of the community through the development of networks of information, knowledge and business strategies useful to be practiced and utilized together.

Baldacchino (2009), stated that entrepreneurship is the ability to be creative and innovative which is used as the base, tips, and resources to find opportunities for success. The essence of entrepreneurship is the ability to create something new and different through creative thinking and innovative action to create opportunities. Creativity is the ability to develope new ideas and new ways of solving problems and finding 
opportunities. The point of creativity is to think of something new and different. While innovation is the ability to apply creativity in the framework of solving the problem and finding opportunities. The point of innovation is the ability to do something new and different. An entrepreneur must have new ideas resulting from a creativity. Creativity is what will bring entrepreneurs to innovate the business.

Drucker (1985), defines entrepreneurship as the spirit, skills, attitudes, behavior of individuals in handling business or activity that leads to the search for, create, implement ways of working, technologies, and new products to improve efficiency in order to provide better services and or obtain greater profits. There are five essentials of entrepreneurship, namely (1) a strong ability to work with a spirit of independence (especially economic); (2) the ability to solve problems and make decisions in a systematic, including the courage to take risks; (3) the ability to think and act in a creative and innovative; (4) the ability to work as a conscientious, diligent and productive; and (5) the ability to work in unity based on healt business ethics.

\section{Theory of $x$-Efficiency}

According Leibenstein (1977), with a theoretical model x-Efficiency, assumes that the production function neo-classical is a sham and did not reach the level of efficiency that is actually, because the facts show that man as the driving factor of production does not have the same response in respond to any pressure that occurs as a result of market dynamics. Intertial cost faced by any society is very different, because it will depend on the environmental conditions of demographic and economic factors (Chang, 2007). If a community has a high response in the face of each of the development dynamics of the market, then the pressure will produce the effort that created the low cost of production and increase productivity and competitiveness.

Leibenstein (1977), defines the work effort with four variables. This theory states that every individual has a choice of four combinations to get one of the four most optimal choice. Choice of one of four possible effort called the point, at the level of the bottom character selection option is still positive levels of satisfaction, but proceeds reach the top then move downwards. Swing movement depicts the declining marginal utility of the effort will be negative, and total utility starts to decline.

\section{Empirical model}

Based on the theory, concepts, and the results of previous research, it can be arranged as a research model Figure 3.

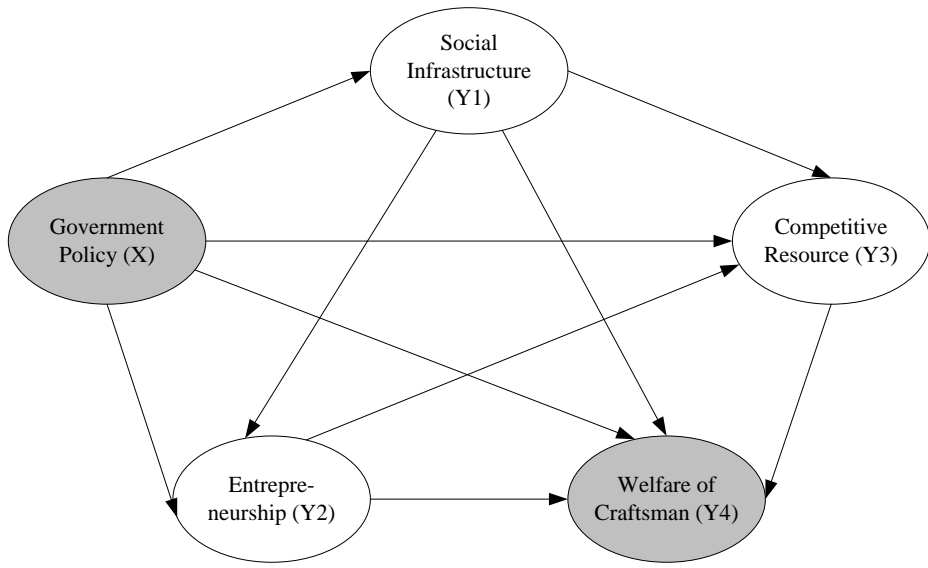

Figure 3: Empirical Model

\section{Research hypotheses}

Hypothesis in this study as many as 16 hypotheses, consisting of 10hipotesis which are direct effects, and six hypotheses that are indirect effect. In addition, the research hypothesis as shown in Table 1.

\section{Research Method}

I. This research uses a quantitative approach that is reinforced by the descriptive analysis. The research location is in Badung Regency, with the object of research is the SME craft. Data was collected through a questionnaire instrument which has proven valid and reliable. Collected data analyzed by using Partial Least Square-Structural Equation Modeling (PLS-SEM).

II. The population in this study were 372 craft SMEs in Badung Regency that are distributed in six district. Furthermore, the sample size was calculated using the formula Slovin $(e=10 \%)$, in order to obtain a sample of 79 SMEs. Sampling technique is stratified random sampling, namely by determining the number of samples per area (district) proportionally, and then respondents selected randomly. Table 1. showing in detail the amount of the population sample in each area (district) in Badung Regency. 
Table 1: Research Hypothesis

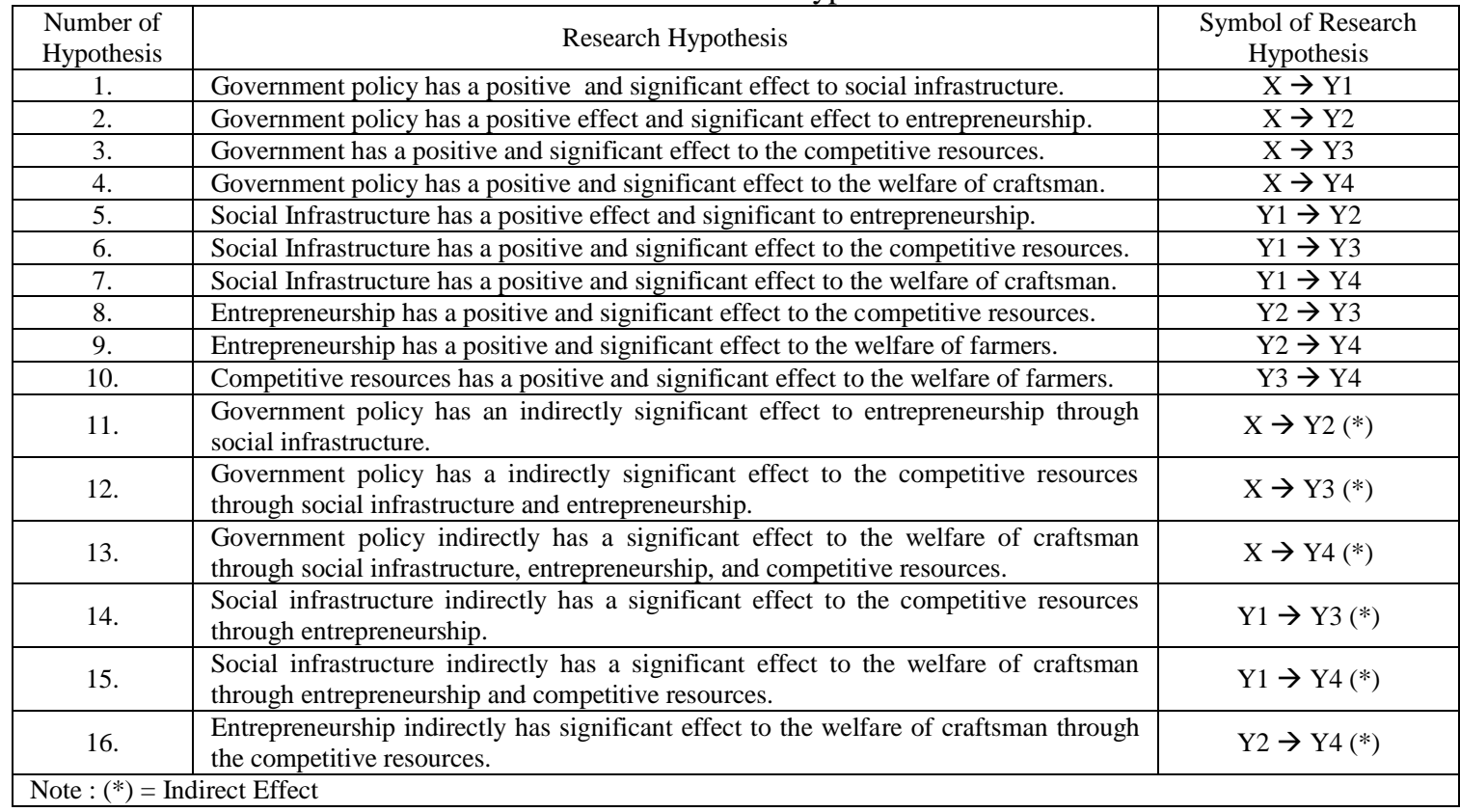

Table 1: The Amount of Population and Sample

\begin{tabular}{|c|c|c|c|c|c|c|c|}
\hline & \multicolumn{6}{|c|}{ Name of District } & \multirow{2}{*}{ Sum } \\
\hline & Abiansemal & Kuta & Mengwi & Kuta Selatan & Kuta Utara & Petang & \\
\hline Population & 123 & 33 & 104 & 17 & 37 & 58 & 372 \\
\hline Sample & 26 & 7 & 22 & 4 & 8 & 12 & 79 \\
\hline
\end{tabular}

\section{Data Analysis And Discussion}

\section{Result of Analysis Data with PLS-SEM}

The first step to interpret the output from the PLS-SEM testing is to test using the outer models. Outer models test done with validity test and reliability test. The results of outer model test show that the research model has suitable with the test criteria. In addition, the result of results outer models test show in Appendix 1 and Appendix 2.

After testing by outer model test, further to estimate the inner models by looking at R-square value and the Qsquare, as in Table 2.

Table 2: The Value of R-square for Endogenous Construct

\begin{tabular}{|l|c|c|}
\hline \multirow{2}{*}{ Endogenous Construct } & R Square & \multirow{2}{*}{ Remark } \\
\cline { 2 - 3 } & $\left(\mathrm{R}^{2}\right)$ & Weak \\
\hline Social Infrastructure (Y1) & 0.063 & Moderat \\
\hline Entrepreneurship (Y2) & 0.606 & Strong \\
\hline Competitive Resources (Y3) & 0.865 & Strong \\
\hline Welfare of Craftsman (Y4) & 0.880 & \\
\hline
\end{tabular}

By using the R-square values in Table 2, the Q-square value is calculated as follows:

$$
\begin{aligned}
Q^{2} & =1-\left\{\left(1-0.063^{2}\right)\left(1-0.606^{2}\right)\left(1-0.865^{2}\right)\left(1-0.880^{2}\right)\right\} \\
& =1-\{(0.996)(0.633)(0.252)(0.226)\} \\
& =1-0.03579=0.964
\end{aligned}
$$

Calculate results for Q-square value is 0964 , which means that 96.4 percent of the variation value of craftsman well-being variable can be explained by the construction in the model of this study. Only for 3.6 percent of the variation of the value changes craftsman welfare variable that can not be explained by the constructions in the research model.

The next stage is to test the direct and indirect influence between the variables. Output of direct influence in Table 3, and the indirect effect is shown in Table 4. 
The Effects of Government Policy on Craftsmen Welfare in Badung Regency of Bali Province; ..

Table 3: Path Coefficients Value

\begin{tabular}{|c|c|c|c|c|}
\hline & Coefficient & $\begin{array}{c}\text { Standard } \\
\text { Deviation }\end{array}$ & T statistics & $P$ values \\
\hline Governement Policy $(\mathrm{X}) \rightarrow$ Social Infrastructure $(\mathrm{Y} 1)$ & 0.252 & 0.093 & 2.721 & 0.007 \\
\hline Governement Policy (X) $\rightarrow$ Entrepreneurship (Y2) & 0.362 & 0.125 & 2.895 & 0.004 \\
\hline Governement Policy (X) $\rightarrow$ Competitive Resources (Y3) & 0.252 & 0.097 & 0.590 & 0.010 \\
\hline Governement Policy (X) $\rightarrow$ Welfare of Craftsman (Y4) & 0.103 & 0.074 & 1.402 & 0.162 \\
\hline Social Infrastructure (Y1) $\rightarrow$ Entrepreneurship (Y2) & 0.604 & 0.098 & 6.192 & 0.000 \\
\hline Social Infrastructure (Y1) $\rightarrow$ Competitive Resources (Y3) & 0.381 & 0.078 & 4.876 & 0.000 \\
\hline Social Infrastructure (Y1) $\rightarrow$ Welfare of Craftsman (Y4) & 0.286 & 0.086 & 3.306 & 0.001 \\
\hline Entrepreneurship (Y2) $\rightarrow$ Competitive Resources (Y3) & 0.480 & 0.092 & 5.209 & 0.000 \\
\hline Entrepreneurship (Y2) $\rightarrow$ Welfare of Craftsman (Y4) & 0.130 & 0.072 & 1.814 & 0.070 \\
\hline Competitive Resources (Y3) $\rightarrow$ Welfare of Craftsman (Y4) & 0.523 & 0.125 & 4.172 & 0.000 \\
\hline
\end{tabular}

Table 4: The Value of Indisrect Effects

\begin{tabular}{|c|c|c|c|c|}
\hline & Coefficient & $\begin{array}{c}\text { Standard } \\
\text { Deviation }\end{array}$ & T statistics & $P$ values \\
\hline Governement Policy (X) $\rightarrow$ Entrepreneurship (Y2) & 0.152 & 0.061 & 2.480 & 0.013 \\
\hline Governement Policy (X) $\rightarrow$ Competitive Resources (Y3) & 0.343 & 0.072 & 4.750 & 0.000 \\
\hline Governement Policy (X) $\rightarrow$ Welfare of Craftsman (Y4) & 0.450 & 0.100 & 4.494 & 0.000 \\
\hline Social Infrastructure (Y1) $\rightarrow$ Competitive Resources (Y3) & 0.290 & 0.078 & 3.714 & 0.000 \\
\hline Social Infrastructure (Y1) $\rightarrow$ Welfare of Craftsman (Y4) & 0.430 & 0.090 & 4.788 & 0.000 \\
\hline Entrepreneurship (Y2) $\rightarrow$ Welfare of Craftsman (Y4) & 0.250 & 0.066 & 3.823 & 0.000 \\
\hline
\end{tabular}

\section{Result of Hypothesis Testing}

BasedTable 3 and Table 4, it can be tested of the research hypothesis. In general, the direct and indirect influence between variables are significant, except on the direct effect of government policies to the welfare of craftsman where the effect is not significant. In addition, the results of research hypothesis testing are shown in Table 5 .

Table 5 : Result of Hypothesis Testing

\begin{tabular}{|c|c|c|}
\hline $\begin{array}{l}\text { Number of } \\
\text { Hypothesis }\end{array}$ & $\begin{array}{l}\text { Result of Hypothesis } \\
\text { Testing }\end{array}$ & Description \\
\hline 1. & Hypothesis Accepted & Government policy has a positive and significant effect to the social infrastructure. \\
\hline 2. & Hypothesis Accepted & Government policy has a positive and significant effect to the entrepreneurship. \\
\hline 3. & Hypothesis Accepted & Government policy has a positive and significant impact to the competitive resources. \\
\hline 4. & Hypothesis Rejected & Government policy has not a significant effect to the craftsman welfare. \\
\hline 5. & Hypothesis Accepted & Social infrastructure has a positive and significant effect to the entrepreneurship. \\
\hline 6. & Hypothesis Accepted & Social infrastructure has a positive and significant impact to the competitive resources. \\
\hline 7. & Hypothesis Accepted & Social infrastructure has a positive and significant effect to the craftsman welfare. \\
\hline 8. & Hypothesis Accepted & Entrepreneurship has a positive and significant impact to the competitive resources. \\
\hline 9. & Hypothesis Accepted & Entrepreneurship has a positive and significant impact to the farmers welfare. \\
\hline 10. & Hypothesis Accepted & Competitive Resources has a positive and significant impact to the farmers welfare. \\
\hline 11. & Hypothesis Accepted & $\begin{array}{l}\text { Government policy indirectly has an significant effect to entrepreneurship through } \\
\text { social infrastructure. }\end{array}$ \\
\hline 12. & Hypothesis Accepted & $\begin{array}{l}\text { Government policy indirectly has a significant effect to the competitive resources } \\
\text { through social infrastructure and entrepreneurship. }\end{array}$ \\
\hline 13. & Hypothesis Accepted & $\begin{array}{l}\text { Government policy indirectly has a significant effect to the craftsman welfare through } \\
\text { social infrastructure, entrepreneurship, and human resources. }\end{array}$ \\
\hline 14. & Hypothesis Accepted & $\begin{array}{l}\text { Social infrastructure indirectly has a significant effect to the competitive resources } \\
\text { through entrepreneurship. }\end{array}$ \\
\hline 15. & Hypothesis Accepted & $\begin{array}{l}\text { Social infrastructure indirectly has a significant effect to the craftsman welfare through } \\
\text { entrepreneurship and competitive resources. }\end{array}$ \\
\hline 16. & Hypothesis Accepted & $\begin{array}{l}\text { Entrepreneurship indirectly has a significant effect to the craftsman welfare through the } \\
\text { competitive resources. }\end{array}$ \\
\hline
\end{tabular}

\section{Direct Effect Between Government Policy, Social Infrastructure, Enterprise, Resource Compete, and Craftsmen Welfare}

Hypothesis testing results show that the direct effect between the research variables entirely positive and significant, except on the direct effect of government policies to the craftsman welfare, where the p-value is worth 0162 (greater than 0.05), which means that the effect is not significant. North (1990), said that there are five functions of the government's policy to provide guidance to businesses, namely (a) the facilities of government policy in resource development, (b) assisting the government in strengthening technology savings on production, (c) the role of government in empowering business world organization more effective and efficient business management, (d) the role of government in the development of our business partners and 
marketing assistance, and (e) the competitiveness of products and institutional development of sustainable businesses.

The government's role could be decisive part in the development of the institutional system that can serve the environmental condition in order to strengthen social entrepreneurship associated with innovation and creativity to flourish. Government policies have a significant effect to infrastruktur social value tstatistic. of 2.721 The value is greater than ttable by 1.96 . Similarly with $\mathrm{p}$ value amounting to 0,007 , which means the effect is significant at the level of 5 percent.

Government policy is also becoming an important fact in moving the production and expansion of employment. The results of this study indicate that government policies has a positive and significant effect to entrepreneurship, where the confidence level of 5 percent, a scoretstatistic of 2.895 which was still greater than the value ttable $=1.96$, so it can be stated that the effect of government policies towards entrepreneurship is significant.

The craftsmen ability is very limited to establish the necessary creativity and innovation in business development. Thus, efforts to develop innovations become an obstacle in establishing the competitiveness of craftsman. In order to empower small businesses, governments in many countries have diverse policy in facilitating the development of innovation in order to promote the progress of small businesses that cover the needs innovation, government assistance in order to develop the skills of employees, as well as efforts to build employee productivity increasingly competitive (Chen and Guan , 2012).

Cook etal.(2003), concluded that government policy be decisive in the development agenda of small businesses in many countries. Government policy is also controlling the direction of development of small businesses that have an impact on the business, the user consumer products as well as other parties (Herrera et al, 2008). The role of government also have a real impact and contribute to the power base of operations and the establishment of public welfare (Wolff, 2002). Governments in many countries also play a role, among others, (1) to encourage the development and mentoring, (2) providing financial assistance, (3) a regulation to protect the business, and (4) the policy of empowerment. Direct government policy is not able to effect in improving the welfare of craftsman. So that happened in Badung, therefore it is need intermediary that bridging government policy.

\section{Indirect Effect Among Government Policy, Social Infrastructure, Enterprise, Resource Compete, and Craftsmen Welfare}

Main independent variable in this study is the policy of the government, with the ultimate goal to improve the craftsman welfare. Given the direct influence of government policy on the welfare of craftsman is not significant, while the social infrastructure, entrepreneurship, and competitive resources proven to mediate significantly, then the indirect effect of government policies on the welfare of craftsman in the Badung regency is full mediation.

The role of entrepreneur theas mediation in order to propel business growth and welfare said by Piere and Sable (1984) as well as Wennekers and Thurik (1999). In the case where government policies regulating carrying out their functions and empowerment in order to strengthen the social infrastructure, including the availability of assets and preservation of natural resources (North, 1990; Kretzman and McKnight, 1993; Wollf, 2002). Social infrastructure as mediation that to strengthen government policies for creating the welfare, recommended by Crocker etal.(1998), which describes the role of local government as a regulator and facilitator, and empowerment through partnership in building public capital.The government policy becomes an important part in mobilizing public capital and social infrastructure for strengthen the local communities to build their welfare (Kretzman and McKnight, 1993).

The Government of Regency Badung continues to work to improve the Craftsman welfare through a variety of programs, which aimed to develop entrepreneurial social infrastructure, entrepreneurship, as well as the craftsmen competitive cresources. Some programs of the Government of Badung Regency in the craft industry are as follows.

1) Developing SMEs Program, means that the business is developing in line with expectations that such activities are conducted:

a) Training industry groups to foster new businesses.

b) Assistance SMEs in overcoming problems faced in terms of both technology and innovation.

c) The development of SMEs is a routine activity undertaken to SMEs to facilitate the interests of the craftsmen.

d) Meeting of business, is a regular activity of each year by gathering businesses in the badung regency to reconcile with the government (Department of Industry Badung Regency and Bali Province) and private parties such as BCIC (Center for Creative Industries Centre), banking, and practitioners with the theme of how to solve the problems and be given a motivation to promote their business. 
2) Enhancement Technology SMEs Program is a technology activities oriented in the use of machinery and marketing products online.

3) QC (Quality Control), in advancing the business industry processing by GMP (Good Manufacturing Product) starting from the sorting / selection, materials process, processing, printing until the packaging the products arranged in sequence and use the Appropriate Technology.

4) Establishing the Association of Craftsmen in Badung Regency (ASPERINDA) were followed by product sales MOU between Dekranasda, associations and BPPT (Agency for Integrated Licensing Services). Tourism industry players must to take care of licensing every effort to buy craft products that produced by craftsman in Badung Regency

5) Products promote by: Exhibition in the region, INACraft (special exhibition of handicraft industry product recognition at the national level every april), Exhibition every Dekranas Anniversary and Mutumanikam (special exhibition of handicraft accessories products).

\section{Conclusion And Implication}

The research results showed that directly, government policy has not significant effect to the craftsman welfare. Therefore, public policy should be realized by various programs and activities to support the craft business conditions so able to realize the craftsman welfare. Furthermore, the role of social infrastructure, entrepreneurship, and competitive resources proven to mediate significantly influence of government policies to the craftsman welfare. Some examples of government programs recommended to improve the craftsman welfare are to facilitate the sale of products by exhibitions, conducting management training and technology, as well as the expansion of handicraft products.

\section{References}

[1] H. Leibenstein and S. Maital, Empirical estimation and partitioning of X-eficiency: A data envelopment approach. The American Economic Review, 82(2), 1992, 428-433.

[2] M. Albert and R. Hahnel, Quiet Revolution in Welfare Economics (Princenton, NJ: Princeton University Press, 1990)

[3] Salvatore, International Economics (Jakarta: Erlangga, 1997).

[4] M.E. Westgate, Physiology of flowering in maize: Identifying avenues to improve kernel set during drought. Proceedings of a Symposium Developing Drought and Low N Tolerance Maize. CIMMYT El Batan Mexico, 1996, 137.

[5] H.A. Kamya, Hardiness and Spiritual Well-Being Among Social Work Students: Implications for Social Work, Journal of Social Work Education, 36, 2000, 231-241.

[6] C.W. Ellison and J. Smith, Toward and Integrative Measure of Health and Well-Being, Journal of Psychology and Theology, 19, $1991,35-48$.

[7] C.K. Chandler, J.M. Holden, C.A. Kolander. Conseling for Spiritual Wellness: Theory and Practise, Journal of Conseling and Development, 71, 1992, 168-175.

[8] T.B. Adams, J.R. Bezner, M.E. Drabbs, R.J. Zambarano, M.A. Steinhardt, Conceptualization and Measurement of the Spiritual and Psychological Dimensions of Wellness in a College Population, Journal of American College Health, 48(4), $2000,165-173$.

[9] C.K. Tsung, Introduction to Geographic Information Systems (New York: McGraw-Hill, 2002).

[10] H. Al Rasyid, Dasar-dasar Statistika Terapan (Badnung: Program Pascasarjana UNPAD, 2000).

[11] M. Hamdi, Decentralization and Regional Development. Paper, Jakarta, 1999.

[12] T. Ndraha, Kybernology (Jakarta: Rineka Cipta, 2000).

[13] C.B. Flora and J.L. Flora, Entrepreneurial Social Infrastructure: A Necessary Ingredient, Annals of the American Academy of Political and Social Science, 529, 1993.

[14] Baldacchino, Entrepreneurial Creativity and Innovation, The First International Conference on Strategic Innovation and Future Creation, University of Malta, Malta, 20089.

[15] P.F. Drucker, Innovation and Entrepreneurship (London: Heinemann, 1985).

[16] H. Leibenstein, Entrepreneurship in general (USA: Oxford University Press, 1977).

[17] E.P.C. Chang, Entrepreneurship And Economic Development And Growth In America: An Investigation At The County Level. Dissertation, Mississippi State University, 2007.

[18] D.C. North. Institutions, Institutional Change, and Economic Performance (Cambridge: Cambridge University Press, 1990).

[19] K. Chen and G. Guan, Mapping the Functionality of China's Regional Innovation Systems: A Structural Approach, China Economic Review, 22, 2011, 11-27.

[20] G. Cook, N. Pandit, D. Milman, A resource-based analysis of bankruptcy law, SMEs and corporate recovery, International Small Business Journal, 30(3), 2003, 275-293.

[21] L. Herrera, M.F.M. Doyague, and M. Nieto, Mobility of public researchers, scientific knowledge transfer, and the firm's innovation process, Journal of Business Research, 63(5), 2010, 510-518.

[22] Wolff. The Effectiveness of Subsidies Revisited: Accounting for Wage and Employment Effects in Business R\&D (Sage Publications, 2002).

[23] M.J. Piere and C.F. Sable, Possibility for Prospertity (New Yprk: Basic Books, 1984).

[24] S. Wennekers and R. Thurik, Linking Entrepreneurship and Economic Growth, Small Business Economics, $13(1), 1999$.

[25] J. Kretzmann, and J.J.D. McKnight, Bulding Communities from the Inside Out: A Path Toward Finding and Mobilizing a Community Development. New York Times Magazine, 1993.

[26] J. Crocker, B. Major, C. Steele, Social Stigma, in Hanbook of Social Psychology (Boston: McGraw-Hill, 1998). 
The Effects of Government Policy on Craftsmen Welfare in Badung Regency of Bali Province; ..

\section{Appendix 1}

\section{APPENDIX}

\begin{tabular}{|c|c|c|c|c|c|c|c|c|}
\hline \multirow{3}{*}{ Indicator } & \multicolumn{8}{|c|}{ Construct } \\
\hline & \multirow{2}{*}{$X$} & \multicolumn{3}{|c|}{$Y_{1}$} & \multirow{2}{*}{$\mathrm{Y}_{2}$} & \multicolumn{2}{|c|}{$\mathrm{Y}_{3}$} & \multirow{2}{*}{$\mathrm{Y}_{4}$} \\
\hline & & $Y_{1.1}$ & $Y_{1.2}$ & $Y_{1.3}$ & & $Y_{3.1}$ & $Y_{3.2}$ & \\
\hline $\mathrm{X}_{1}$ & $\mathbf{0 , 8 5 8}$ & 0,045 & 0,065 & 0,185 & 0,439 & 0,404 & 0,463 & 0,420 \\
\hline $\mathrm{X}_{2}$ & $\mathbf{0 , 9 0 8}$ & 0,157 & 0,194 & 0,189 & 0,478 & 0,513 & 0,490 & 0,517 \\
\hline $\mathrm{X}_{3}$ & 0,911 & 0,128 & 0,098 & 0,242 & 0,450 & 0,537 & 0,546 & 0,481 \\
\hline $\mathrm{X}_{4}$ & 0,908 & 0,299 & 0,142 & 0,247 & 0,528 & 0,558 & 0,600 & 0,575 \\
\hline $\mathrm{X}_{5}$ & 0,793 & 0,099 & 0,102 & 0,187 & 0,311 & 0,379 & 0,408 & 0,399 \\
\hline $\mathrm{Y}_{1.11}$ & 0,305 & $\mathbf{0 , 8 3 3}$ & 0,387 & 0,288 & 0,622 & 0,631 & 0,614 & 0,698 \\
\hline $\mathrm{Y}_{1.12}$ & 0,121 & $\mathbf{0 , 8 2 1}$ & 0,297 & 0,302 & 0,410 & 0,561 & 0,451 & 0,607 \\
\hline $\mathrm{Y}_{1.13}$ & 0,013 & 0,743 & 0,194 & 0,173 & 0,337 & 0,427 & 0,502 & 0,501 \\
\hline $\mathrm{Y}_{1.14}$ & 0,090 & 0,806 & 0,290 & 0,164 & 0,399 & 0,462 & 0,459 & 0,522 \\
\hline $\mathrm{Y}_{1.21}$ & 0,258 & 0,330 & 0,896 & 0,203 & 0,492 & 0,487 & 0,423 & 0,503 \\
\hline $\mathrm{Y}_{1.22}$ & 0,135 & 0,401 & 0,920 & 0,227 & 0,491 & 0,554 & 0,444 & 0,550 \\
\hline $\mathrm{Y}_{1.23}$ & $-0,068$ & 0,211 & 0,781 & 0,166 & 0,278 & 0,291 & 0,139 & 0,307 \\
\hline $\mathrm{Y}_{1.31}$ & 0,114 & 0,267 & 0,318 & 0,817 & 0,431 & 0,505 & 0,396 & 0,408 \\
\hline $\mathrm{Y}_{1.32}$ & 0,288 & 0,230 & 0,128 & $\mathbf{0 , 8 2 0}$ & 0,343 & 0,435 & 0,347 & 0,368 \\
\hline $\mathrm{Y}_{1.33}$ & 0,202 & 0,209 & 0,075 & 0,784 & 0,310 & 0,369 & 0,270 & 0,305 \\
\hline $\mathrm{Y}_{2.1}$ & 0,454 & 0,488 & 0,487 & 0,394 & 0,848 & 0,700 & 0,709 & 0,698 \\
\hline $\mathrm{Y}_{2.2}$ & 0,423 & 0,502 & 0,449 & 0,267 & 0,787 & 0,700 & 0,674 & 0,719 \\
\hline $\mathrm{Y}_{2.3}$ & 0,394 & 0,418 & 0,394 & 0,385 & 0,846 & 0,687 & 0,662 & 0,729 \\
\hline $\mathrm{Y}_{2.4}$ & 0,407 & 0,471 & 0,270 & 0,414 & $\mathbf{0 , 7 2 3}$ & 0,529 & 0,692 & 0,589 \\
\hline $\mathrm{Y}_{2.5}$ & 0,386 & 0,374 & 0,374 & 0,377 & $\mathbf{0 , 8 0 7}$ & 0,664 & 0,670 & 0,626 \\
\hline$Y_{3.11}$ & 0,198 & 0,536 & 0,440 & 0,368 & 0,637 & 0,645 & 0,561 & 0,578 \\
\hline$Y_{3.12}$ & 0,362 & 0,400 & 0,453 & 0,404 & 0,599 & 0,713 & 0,667 & 0,604 \\
\hline $\mathrm{Y}_{3.13}$ & 0,469 & 0,540 & 0,373 & 0,542 & 0,661 & 0,779 & 0,696 & 0,717 \\
\hline$Y_{3.14}$ & 0,490 & 0,567 & 0,393 & 0,387 & 0,636 & 0,832 & 0,627 & 0,775 \\
\hline$Y_{3.15}$ & 0,492 & 0,545 & 0,381 & 0,413 & 0,636 & 0,841 & 0,638 & 0,765 \\
\hline$Y_{3.16}$ & 0,501 & 0,430 & 0,385 & 0,395 & 0,600 & 0,768 & 0,567 & 0,645 \\
\hline$Y_{3.21}$ & 0,464 & 0,500 & 0,237 & 0,351 & 0,605 & 0,584 & 0,800 & 0,610 \\
\hline$Y_{3.22}$ & 0,478 & 0,517 & 0,324 & 0,420 & 0,757 & 0,699 & 0,869 & 0,738 \\
\hline$Y_{3.23}$ & 0,528 & 0,495 & 0,300 & 0,356 & 0,686 & 0,687 & $\mathbf{0 , 8 2 2}$ & 0,687 \\
\hline$Y_{3.24}$ & 0,497 & 0,581 & 0,408 & 0,302 & 0,714 & 0,720 & 0,849 & 0,796 \\
\hline $\mathrm{Y}_{3.25}$ & 0.467 & 0.566 & 0.417 & 0.357 & 0.784 & 0.739 & $\mathbf{0 . 8 5 7}$ & 0.774 \\
\hline $\mathrm{Y}_{4.1}$ & 0.458 & 0.675 & 0.536 & 0.478 & 0.825 & 0.831 & 0.776 & 0.914 \\
\hline $\mathrm{Y}_{4.2}$ & 0.482 & 0.707 & 0.422 & 0.409 & 0.737 & 0.764 & 0.769 & 0.907 \\
\hline $\mathrm{Y}_{4.3}$ & 0.495 & 0.639 & 0.558 & 0.330 & 0.744 & 0.776 & 0.789 & 0.891 \\
\hline $\mathrm{Y}_{4.4}$ & 0.569 & 0.637 & 0.422 & 0.416 & 0.734 & 0.864 & 0.789 & 0.913 \\
\hline
\end{tabular}

Appendix 2

Cronbach's Alpha and Composite Reliability

\begin{tabular}{|c|c|c|c|c|c|}
\hline \multicolumn{2}{|c|}{ Construct } & Cronbach's Alpha & rho_A & $\begin{array}{c}\text { Composite } \\
\text { Reliability }\end{array}$ & $\begin{array}{c}\text { Average Variance Extracted } \\
\text { (AVE) }\end{array}$ \\
\hline $\mathrm{X}$ & & 0,924 & 0,941 & 0,943 & 0,769 \\
\hline $\mathrm{Y}_{1}$ & $\mathrm{Y}_{1.1}$ & 0,814 & 0,823 & 0,877 & 0,642 \\
\cline { 2 - 6 } & $\mathrm{Y}_{1.2}$ & 0,836 & 0,862 & 0,901 & 0,753 \\
\cline { 2 - 6 } & $\mathrm{Y}_{1.3}$ & 0,736 & 0,747 & 0,849 & 0,652 \\
\hline $\mathrm{Y}_{2}$ & & 0,862 & 0,865 & 0,901 & 0,646 \\
\hline $\mathrm{Y}_{3}$ & $\mathrm{Y}_{3.1}$ & 0,857 & 0,862 & 0,894 & 0,587 \\
\cline { 2 - 6 } & $\mathrm{Y}_{3.2}$ & 0,895 & 0,897 & 0,923 & 0,705 \\
\hline $\mathrm{Y}_{4}$ & & 0,927 & 0,928 & 0,948 & 0,821 \\
\hline
\end{tabular}

